\title{
ASPECTS OF CONTINUITY AND CHANGE IN THE REPRESENTATION OF THE GODDESS TAYT
}

\author{
Dorotea Wollnerová ${ }^{1}$
}

\begin{abstract}
The Egyptian goddess Tayt has always been connected with weaving, linen, and the clothing of the deities. Overall, one can observe a clear continuity in the depiction of Tayt in a purely anthropomorphic form from its earlier occurrences during the New Kingdom well into Roman times. However, during the Late and the PtolemaicRoman Period Tayt appears in several different forms, she is at times represented with the head of a lioness or with a cobra's head. The article takes an in-depth look at the various occasions in which discontinuity can be observed in the traditional portrayal of the goddess and aims to provide answers to the various reasons and implications behind this change in appearance.
\end{abstract}

KEYWORDS: Tayt - Egyptian religion - iconography - offering - Ptolemaic and Roman Period

\section{Introduction}

Throughout ancient Egyptian history, the goddess Tayt has always been connected with weaving, linen, and the clothing of the deities. ${ }^{2}$ Although she is attested already in the Pyramid Texts, her oldest known depictions derive from the New Kingdom overall. One can observe a clear continuity in the depiction of Tayt in a purely anthropomorphic form from its earliest occurrences during the New Kingdom well into Roman times. This standard depiction of the goddess even let El-Saady claim that she was only ever portrayed as such. ${ }^{3}$ The latter assertion was already invalidated a mere two years later when Cruz-Uribe ${ }^{4}$ observed that Tayt during the Late and the Ptolemaic-Roman Period could be depicted in several different forms, typical of so many ancient Egyptian deities - she is at times represented with the head of a lioness ${ }^{5}$ or with a cobra's head ${ }^{6}$. This article focuses on the different variants of her representation, studies their context and presents possible reasons that could have caused the choice of a particular display of this goddess.

1 Contact: Dorotea Wollnerová, Czech Institute of Egyptology, Charles University in Prague, Czech Republic; e-mail: dorotea.wollnerova@gmail.com. The paper was written within the framework of the project 'Continuity, Discontinuity and Change. Adaptation Strategies of Individuals and Communities in Egypt at Times of Internal and External Transformations' supported by the Czech Science Foundation (grant no. 19-07268S).

2 LÄ VI, p. 185; Wilkinson 2003, p. 168.

3 El-Saady 1994, p. 214.

4 Cruz-Uribe 1996, p. 20.

5 Edfu I, 127, 7-8, Pl. XXIb; Edfu I, 129, 11-12, Pl. XXIb; Dendera I, 154, 70, Pl. LXXXIX.

6 Davies 1953, p. 15, Pl. 9. 


\section{The role and function of Tayt}

In the Old Kingdom Pyramid Texts (PT), Tayt is identified with the Eye of Horus and connected with Neith ${ }^{7}$, identified with Isis $^{8}$, while the king is clothed by her ${ }^{9}$. During the Middle Kingdom, Tayt is attested as the one who produces linen (e.g. in the Coffin Texts $[\mathrm{CT}]^{10}$ ), and she relates to other deities, e.g. Ptah (Tayt wove his cloak ${ }^{11}$ ). She is mentioned even in the most famous literary text from Ancient Egypt - The Story of Sinuhe: 'Sheets of linen and wrappings will be prepared for you, bandages from the hand of Tayt, it will be made for your funeral procession on the day of joining the land. ${ }^{\prime 2}$ At this time, her name only features in texts, she is never depicted.

The common view on the nature of Tayt as a goddess involved with weaving and the wrapping of the dead with the cloth that she has manufactured still continues throughout the New Kingdom, but what is new is a shift from purely funerary textual corpora to other types of texts. She occurs for example regularly in a temple context, clothing the gods with the garment that she produces (e.g. in Abydos). ${ }^{13}$ Her name is now also mentioned in medical texts, ${ }^{14}$ while she is likewise associated with liturgical fumigation along with fellow deities Hedjhetep and Shesmu (The Songs of the Harpers from the tomb of Neferhetep, TT50). ${ }^{15}$

The connection of Tayt with Hedjhetep and Shesmu occurs very often in other contexts as well, especially in temple scenes during the Ptolemaic and Roman Period. ${ }^{16}$ At this time, Tayt adopted several new attributes - she is mw.t ntr.w (mother of the gods) and hnw.t ntr.wt (lady of the goddesses). ${ }^{17}$ The king is said to be the son of Hedjhetep, born of Tayt ${ }^{\prime}{ }^{18}$ She also extends the terror of the gods ${ }^{19}$ or herself, ${ }^{20}$ eliminates violence, ${ }^{21}$ and makes the bodies of the gods thrive in their places. ${ }^{22}$

7 'May you awake in peace! Awake, Tayt, in peace! Awake, you of Tayt-town, in peace! Horus's eye in Dep, in peace! Horus's eye in the Red-Crown compounds, in peace!' - PT 81; Allen 2005, p. 25

8 'Greetings, Tayt on the lip of the great nest! Associate the god to his brother, whether you are present or not, whether are ever-present or not. Care for my head so that it won't pass away, and collect my bones so that they won't pass away, and give love for me into the belly of every god who will see me' PT 415; Allen 2005, p. 89

9 'As the Great One lies on his mother Nut, your mother Tayt will clothe you and carry you to the sky in her identity of a kite. Foundling, she has found her Horus.' - PT 417; Allen 2005, p. 89

10 'Ho N! Anubis the embalmer will enwrap you with wrappings from the hand of Tayt.' - CT 345; Faulkner 2004, p. 280

11 'The horizon is shut away, the pillars are broken [...], its curtain is the cloak of Ptah which Tayt herself wove.' - CT 60; Faulkner 2004, p. 55, for the relation between Ptah, clothing and Tayt see also Altenmüller 1975, p. 65.

12 Sinuhet B 191-193, Míčková and Wollnerová 2018.

13 Gardiner 1935, Pl. 8, 16.

14 pLondon 41, 13, 15; pLondon 42, 14, 1; Wreszinski 1912, p. 157.

15 Lichtheim 1945, pp. 198-199.

16 Backes 2001; Zecchi 2001.

17 e.g. Dendera IV, 101, 12; Dendera VIII, 91, 9.

18 Dendera III, 119, 7.

19 Dendera IV, 126, 11.

20 Dendera III, 12, 8.

21 Dendera III,156, 17.

Dendera IV, 101, 13. 


\section{Variants of the representation of Tayt}

Although Tayt herself is attested already in the Pyramid Texts, the oldest known depictions of Tayt derive from the New Kingdom tomb of Ramses VI (KV 9), where she appears in the context of the sixth hour of the Amduat sitting behind 'the Bull With The Voice of Thunder' and 'the Divine Eye of $\mathrm{Ra}^{\prime}{ }^{23}$ in the guise of a woman with no others significant attributes, and identified as Isis-Tayt. ${ }^{24}$ The same female form can be observed once again in the Amduat where she has a star above her head and is identified with the seventh hour. ${ }^{25}$

In the wsjr-hks-dt chapel in Karnak, on blocks dated to the time of Osorkon IV, Tayt is depicted in a very typical position, bringing two folded pieces of linen. ${ }^{26}$ During the Late Period (Darius I), the goddess can be found likewise in the el-Hibis temple in Kharga Oasis. ${ }^{27}$

The widest spread of Tayt's representation is definitely during the Ptolemaic-Roman Period, and especially in the Hathor temple of Dendera. In most cases the goddess is portrayed in a purely anthropomorphic form - a female standing, sitting, or kneeling holds in her hands folded piece(s) of linen [Fig. 1], ${ }^{28}$ boxes for linen [Fig. 2] ${ }^{29}$ or the w3s sceptre and ${ }^{n} h$-sign [Fig. 3]. ${ }^{30} \mathrm{~A}$ very typical position also involves her carrying a plate heaped with a variety of linen offerings, usually as part of a procession with other deities. This can be observed for example in the temple of Kom Ombo (the rule of Ptolemy VIII Euergetes II) [Fig. 4], ${ }^{31}$ in the Opet temple (the rule of Augustus) ${ }^{32}$, or in Medamud (the time of Nerva). ${ }^{33}$ She can be also represented on sarcophagi as a seated mourning female figure with one hand in front of the face as a sign of sorrow. ${ }^{34}$

Cruz-Uribe ${ }^{35}$ mentions other depictions from the tomb of Petosiris in the Dakhla Oasis $^{36}$ and Tuna el-Gebel ${ }^{37}$ dated to the Roman Period. The figures there do not have a label, but according to him the identification with Tayt can be inferred from the context, especially the placement near the bier of the deceased holding a cloth and standing behind Isis and/or Nephthys. These two are the only other goddesses that can be seen in this context while holding cloth/linen bandages.

However, next to these typical, frequently attested, anthropomorphic depictions of Tayt, the goddess is also portrayed in a completely different guise: a) anthropomorphic

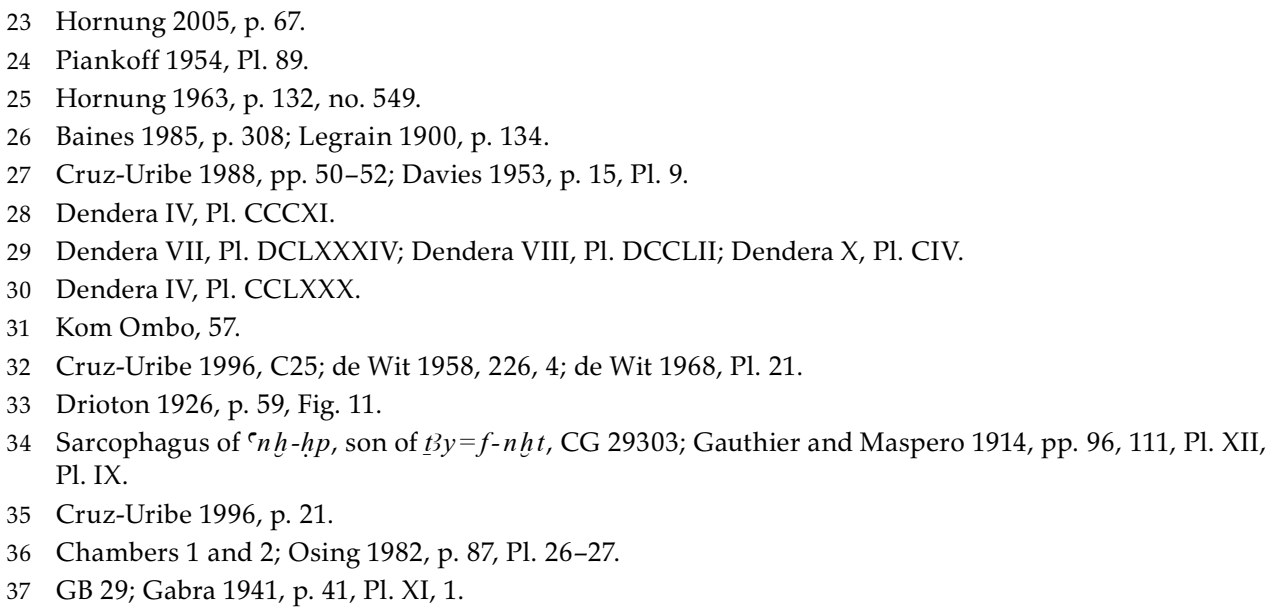




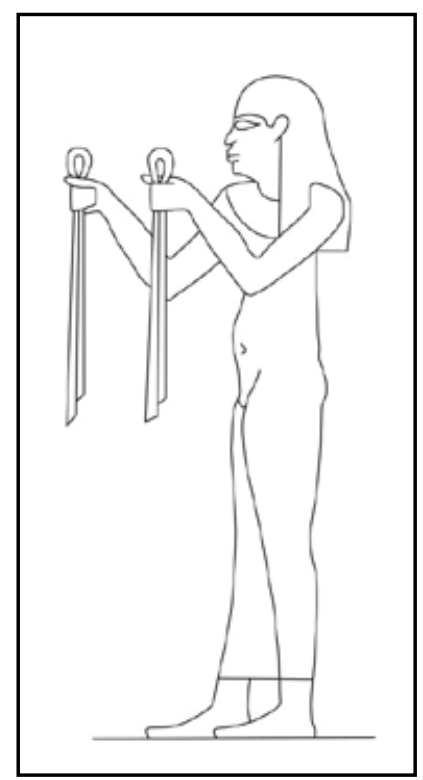

Fig. 1. Tayt offering a linen,

Dendera (after D IV, Pl. CCCXI).

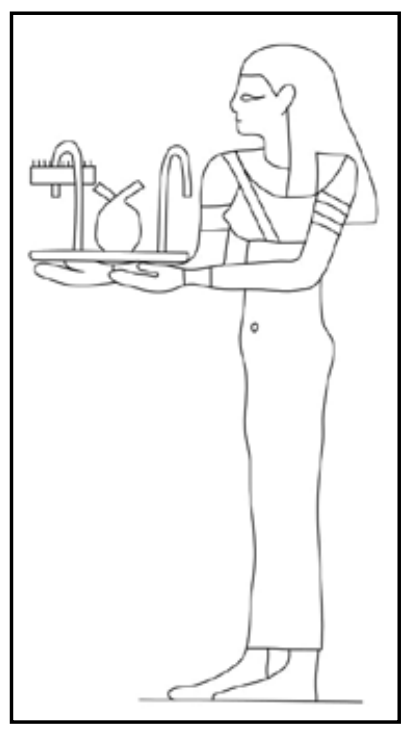

Fig. 4. Tayt with a plate of linen offerings, Kom Ombo (after KO 57).

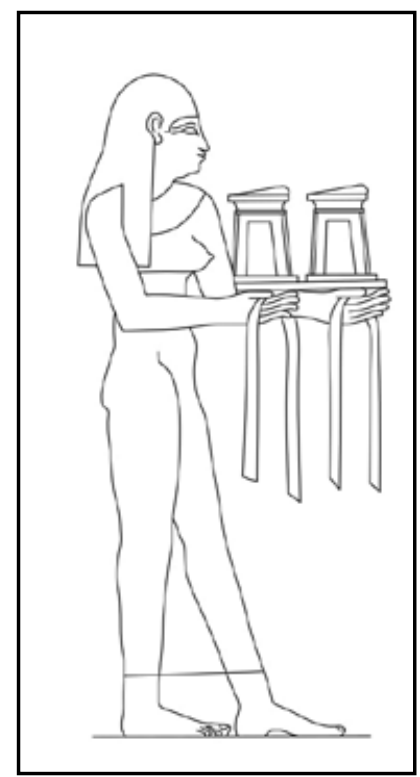

Fig. 2. Tayt in the economic procession, Dendera (after D VII, Pl. DCLXXXIV).

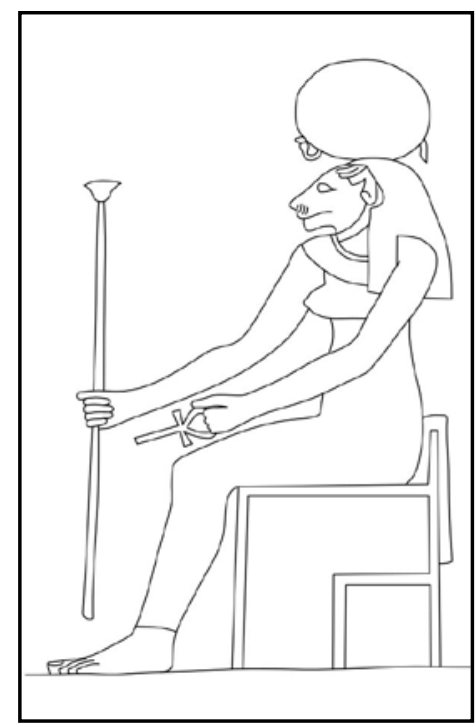

Fig. 5. Tayt with the head of a lioness, Edfu.

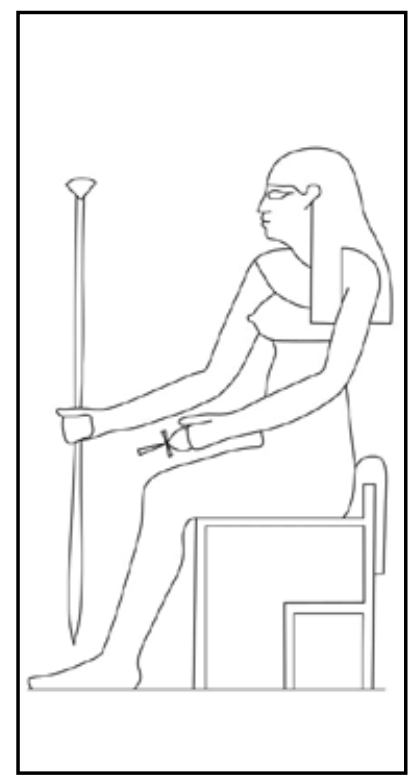

Fig. 3. Tayt with the w3s sceptre and ' $n$ h-sign, Dendera (after D IV, Pl. CCLXXX).

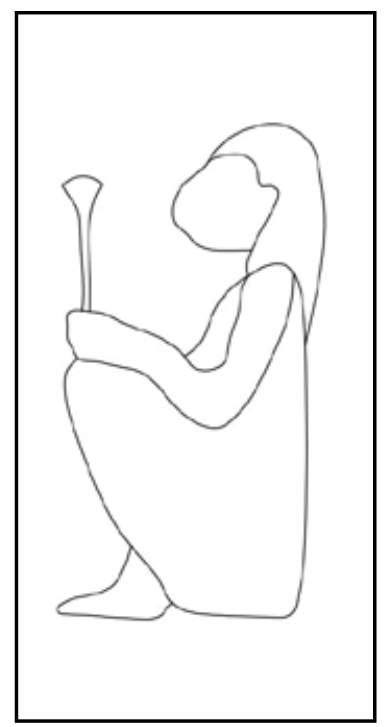

Fig. 6. Tayt with the head of a lioness, Dendera (after D I, Pl. LXXIX). 
with the head of a lioness, b) as a snake with the head of a lioness, and c) one unique example of an anthropomorphic form with the head of a cobra.

\section{Tayt with the head of a lioness}

Tayt is depicted as a woman with the head of a lioness in the second and the third register on the south wall of the Chamber of Linen in Edfu where the king offers jrtjw and $j d m j$ linen $^{38}$ and mnph cloth $^{39}$ to a row of six gods or goddesses. Tayt is depicted sitting, while portrayed with the head of a lioness and sun disk on top of it [Fig. 5]. In the third register, there are four goddesses of the same feline appearance (Tayt, Iret-Ra, Wadjet, Iret-Hor), apparently symmetrically to the four Renenets with snake's head in the same setting on the opposite, north wall.

There are also some occurrences of Tayt with a lioness' head in Dendera. In the frieze of the exterior west wall of the sanctuary, Tayt sits while receiving the $m n h$.t $t$-linen from the king in the scene entitled hnk mnh.t (offering of the mnh.t-linen) [Fig. 6]. ${ }^{40}$ A standing Tayt with the head of a lioness (or some type of feline) occurs in the line of deities in the frieze of the Chamber of the Ennead in the Roman mammisi in Dendera, ${ }^{41}$ where she receives the necklace offered by the king. In this case, it is necessary to disclose that every second goddess in this line-up has this feline shape while alternating with figures in human guise, so there is a definite different pattern of representation at work in this instance, not directly related to the figure of Tayt. In the above-cited frieze of the exterior wall of the sanctuary, the lioness's form of Tayt has probably a similar explanation, because many deities in the friezes of all exterior walls of the sanctuary have this specific appearance, while the lioness regularly alternates with other animal or human forms.

The crucial question is why Tayt is regularly portrayed as a woman, but occasionally also as a lioness? What is the key to understanding this diversity in her representations?

The answer may revolve around the position and function Tayt assumes in each specific scene. Looking at the aforementioned figures, one observes that in the majority of cases Tayt is the one who is presenting the offering - linen -, and in these depictions, she always has an anthropomorphic form. However, the above-mentioned Tayts with the head of a lioness are always on 'the other side of the scene' - she is now the one to whom the offering is brought, she is one of the recipients.

Although this explanation seems acceptable, one scene may appear to interfere with this theory. On the north wall of the Chamber of Linen in Dendera, Tayt has an anthropomorphic form although she is in the position of the recipient of the offering. ${ }^{42}$ The inscription above the fifth sitting person in the second register says:

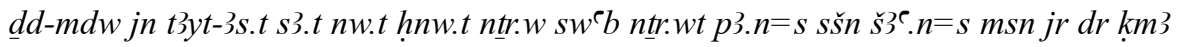

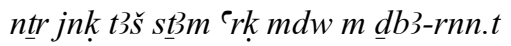

$38 \quad 2^{\text {nd }}$ reg.; Edfu I, 127, 7-8, P. XXIb.

$393^{\text {rd }}$ reg.; Edfu I, 129, 11-12, Pl. XXIb.

40 Dendera I, 154, 70', Pl. LXXIX.

41 Dendera Mammisi, 197, 10 $0^{\circ}$ Pl. LXIX, C.

42 Dendera IV, 125, 5-6, Pl. CCLXXX; Cauville 2001, pp. 216-217. 
Recitation by Tayt-Isis, the daughter of Nut, the lady of gods, who purifies the goddesses, she has started to weave, she has begun to spin, the one who makes $d r$-cloth, who creates the $n t r$-cloth, who unites what is divided, who clothes and dons the $m d w$-staff with the cloth of Renenet.

According to $\mathrm{LGG}^{43}$ there are only two occurrences of Tayt-Isis. Apart from this one in Dendera, she is, firstly, mentioned in the inscription related to the divinities above the offering scene in the Vestibule of the Treasury in Edfu. ${ }^{44}$ The inscription does not only contain the same name but also a very similar (almost identical) description of the general activities of Tayt. The excerpt of this inscription reads:

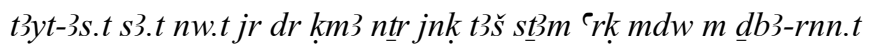

Tayt-Isis, the daughter of Nut, who makes $d r$-cloth, who creates $n t r$-cloth, who unites what is divided, who clothes and dons the $m d w$-staff with the cloth of Renenet.

Tayt is portrayed as a woman in the Edfu publication, ${ }^{45}$ however, Stefan Baumann published a corrected drawing of this scene, and it shows that the last two sitting deities in the row are very damaged, and the faces are not recognizable. ${ }^{46}$ Therefore, it is impossible to decide whether Tayt was represented as a woman or if she had the head of a lioness.

The reason why Tayt in the Chamber of Linen in Dendera does not have the head of a lioness, as she has in other occurrences of this goddess in the position of the one who is offered gifts, is that, in fact, this sitting woman (even though named as Tayt just next to the depiction) is not Tayt, but Tayt-Isis. The use of the head of a lioness for Tayt appears hence to be limited to those occasions when she appears solely under the name Tayt.

Since the Old Kingdom, lioness goddesses were represented as the mother of the king (PT 262 - 'Unis has been conceived by Sekhmet, and Shezmetet is the one who gave birth to Unis'), who suckled him and hugged him. ${ }^{47}$ The king in Ptolemaic temples is often titled as 'the son of Tayt', ${ }^{48}$ 'begot from Tayt ${ }^{\prime 49}$, or the one who is 'suckled by Tayt'..$^{50}$ Tayt in this period also often bears the epithet 'mother of the gods' ${ }^{51}$ It is, therefore, possible that the new way of depicting Tayt relates to the new attributes that she acquires in the Ptolemaic Period when she is perceived as a mother who takes care of her son and protects him through the different kinds of linen that she endows him with.

43 LGG VII, 362.

44 Edfu II, 163, 14-15. There are also two appearances of Isis-Tayt in the tomb of Ramses IV; LGG I, p. 78; Hornung 1987, pp. 478, 479, Nr. 421.

45 Edfu II, 163-164, Pl. XLIIb.

46 Baumann 2013, Abb. 2.

Borchardt 1907, Abb. 21, 23; Fakhry 1961, p. 126, Fig. 141, frontispiece.

e.g. Edfu I, 98, 4.

Dendera III, 12, 8-9.

Dendera IV, 265, 13; Dendera VIII, 91, 9. 
Three attestations of the depiction of Tayt as a snake with the lioness' head have been identified. All of them occur among the long lines of deities in friezes, two in the Offering Hall of the temple of Dendera ${ }^{52}$ and one in the sanctuary of the nearby Roman mammisi. ${ }^{53}$ In my opinion, the rules of the above-suggested theory cannot be applied to these depictions, because in these cases there is unmistakably another pattern at work - every second deity has the form of a lioness headed snake and in the mammisi they even alternate with anthropomorphic gods with a falcon head. The general pattern in these friezes clearly overrides the Tayt-specific pattern.

\section{Tayt with a head of a cobra}

A very rare representation of the goddess Tayt can be found in the el-Hibis temple in the Kharga Oasis [Fig. 7]. ${ }^{54}$ On the north wall of the Hypostyle hall B, a woman with the head of a cobra offers linen to Amun-Ra, the main god of the temple, Osiris and Isis. The inscription clearly indicates that it is Tayt. A goddess with the same appearance stands on the left of the linen offering scene and Cruz-Uribe suggests that it is also Tayt. ${ }^{55}$ Unfortunately, apart from the same form, there is no clear evidence that could prove her identity, because the inscription does not mention linen and the inscription listing the name of this goddess is damaged, while the associated epithets are too general to be able to attribute to a specific goddess.

Another connection between Tayt and the cobra can be found in the ritual of fumigation for the cobra executed by the $j n-m w t=f$ priest. ${ }^{56}$ The name of Tayt has the determinative of the cobra and she is named in the list of other goddesses with the same determinative. Therefore, one can assume that she is depicted as such, because it is part of the larger pattern in this list, once again overriding the pattern typical for Tayt.

\section{Tayt as a solar deity}

Looking at all variations of the representations of Tayt, it appears that the most common aspect to which they refer and which they wanted to emphasize was the light and the sun. The Tayt-lioness in the Chamber of Linen in Edfu has the sun disk with the uraeus on her head and the lion itself has been often identified as a solar deity. ${ }^{57}$ The

52 Dendera VII, 55, $12^{\circ} ; 58,40^{\circ}$, Pl. DCXXX, DCXXXII.

Dendera Mammisi, $120,33^{\circ}$, Pl. LXI.

Cruz-Uribe 1988, pp. 50-52; Davies 1953, p. 15, Pl. 9.

Cruz-Uribe 1996, p. 20.

e.g. Edfu III, 160, 2; 166, 6-7; Edfu IV, 226, 11.

de Wit 1955, pp. 138-147.

Fig. 7. Tayt with a head of a cobra, el-Hibis (after Davies 1953, Pl. 9).

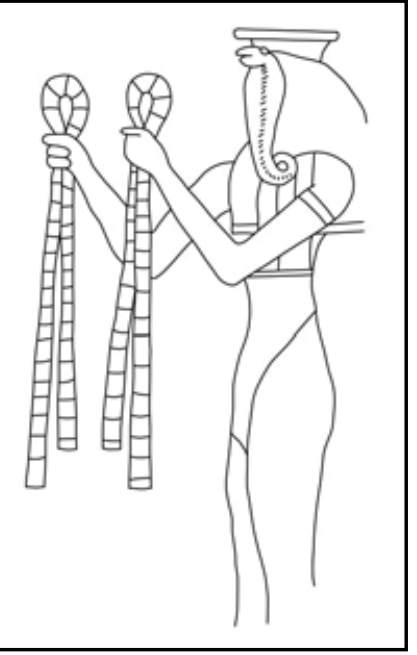


connection between the uraeus (the form in which Tayt is represented in el-Hibis) and the sun is very common. ${ }^{58}$ The recitation of Amun receiving the linen offering from Tayt in el-Hibis ${ }^{59}$ quotes the offering of the jdmj-linen from the daily ritual for Amun, ${ }^{60}$ that also mentions light and illumination:

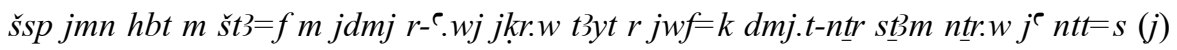

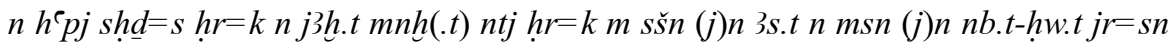
$s \check{s} p(. t) n j m n-r^{c} h b t m 3^{c}-h r w=k r h f t j w=k j r(. t)-r^{c} n b(. t) t 3 . w j$

May Amun of Hibis receive his $\check{s} t$-cloth of $j d m j$-linen, the excellent work of Tayt for your flesh. Demit-netjer(?) ${ }^{61}<$ she $>$ clothes the gods, her impurities are washed away by Hapi, she illuminates your face with sunlight. The mnh.t-cloth that is on you is one that is spun by Isis and woven by Nephthys ${ }^{62}$, they make the bright-cloth of Amun-Ra of Hibis, so that you may be justified against your enemies. The Eye of Ra, lord of both lands.

Tayt herself is often described with connection to light, she is 'the mistress of light' ${ }^{63}$, 'the female sun disk that fills the land with gold dust' (i.e. the morning sun) ${ }^{64}$, or she is 'installed as the female sun disk' ${ }^{65}$ The bright cloth (sšp.t) is moreover one of the offerings that Tayt brings. ${ }^{66}$

\section{Conclusion}

Even though known since the Old Kingdom, the representation of the goddess Tayt first appears during the New Kingdom. However, the by far largest number of her depictions derive from the Ptolemaic and Roman Period, mostly from temple scenes. Throughout this time Tayt was commonly represented as a woman. The predominance of this guise let El-Saady ${ }^{67}$ conclude that this anthropomorphic form is her sole appearance. Nevertheless, Cruz-Uribe ${ }^{68}$ pointed out that the depiction of Tayt as a woman is the most common, but some cases break this continuity in her appearance.

Besides the many depictions of a purely anthropomorphic form, a few Tayts with a lioness' head are also attested. As was suggested in this study, the factor that was decisive for the ancient priests to use one or the other form could relate to her specific position and function within an individual offering scene - whether she presents the offering or whether she is its recipient. The reason why she has the head of a lioness only while receiving the offerings remains unclear.

\footnotetext{
58 The development of its relationship is described in Westendorf 1961.

59 Davies 1953, p. 15, Pl. 9.

60 Moret 1902, pp. 187-188; parallel text also occurs in Edfu; Edfu I, 122, 8-12.

61 For variants of writing of Demit-netjer see LGG VII, 541b.

62 Wilson 1997, pp. 930-931.

63 Dendera VIII, 157, 13.

64 Dendera VIII, 157, 13.

65 Dendera III, 156, 17.

66 Dendera IV, 179, 14.

67 El-Saady 1994, p. 214.

68 Cruz-Uribe 1996, p. 20.
} 
Keeping in mind the sophisticated and complicated patterns in the decorative programs of Egyptian monuments (and especially of Ptolemaic and Roman temples) ${ }^{69}$ we can presume that the priests did not choose the head of a lioness or the cobra to portray Tayt accidentally, but they undoubtedly had a very good reason, most likely related to some aspects of this goddess that they wished to express in this matter.

Tayt is a very ancient goddess of the Egyptian pantheon who, as has been mentioned, took care of the king since the Old Kingdom. This study shows two interesting and very typical aspects of an overall development in expressing Egyptian religious beliefs. The first one is continuity - the long-lasting tradition of the king who is equipped with linen from the hands of Tayt because it ensures the protection of his body. The notion of this protection is very stable and remains unchanged throughout all of Egyptian history from the Old Kingdom until the Ptolemaic and Roman Period. During the New Kingdom, the ancient Egyptian priests decided on development and provided for the first time this very ancient deity with a visual appearance. From this point onward, Tayt was continually represented, predominantly, as a woman, usually bringing a linen offering.

On the other hand, an incessant development and enlargement of associated attributes of this goddess can be observed, and some of these characteristics acquired over time, such as her maternal aspect and the importance of illumination, are newly reflected in the way that she is portrayed: the purely anthropomorphic form was supplemented with the guises of the lioness and the cobra. This study hence indicates both the continuity of the tradition of religious ideas and, at the same time, the constant change of the forms of their expression.

\section{Acknowledgements}

I would like to thank Filip Coppens for his help, support, and comments on this article.

\section{Literature:}

Altenmüller, B. (1975). Synkretismus in den Sargtexten. Göttinger Orientforschungen. Veröffentlichungen des Sonderforschungsbereiches Orientalistik an der Georg-AugustUniversität Göttingen. IV. Reihe: Ägypten. Band 7. Wiesbaden.

Backes, B. (2001). Rituelle Wirklichkeit: über Erscheinung und Wirkungsbereich des Webergottes Hedjhotep und den gedanklichen Umgang mit einer Gottes-Konzeption im Alten Ägypten. Rites égyptiens 9. Turnhout.

Baines, J. (1985). Fecundity Figures. Egyptian Personification and the Iconology of a Genre. Warminster.

Baumann, S. (2013). Der saisonale Aspektder Ressortgötterin der Opfereingangskammer von Edfu. Studien zur Altägyptischen Kultur 42, pp. 37-57. 
Beinlich, H. (2011). Die Photos der Preussischen Expedition 1908-1910 nach Nubien. Teil 3, Photos 400-599. Dettelbach.

Borchardt, L. (1907). Das Grabdenkmal des Königs Ne-user-re. Leipzig.

Cauville, S. (2001). Dendara IV. Traduction. Orientalia Lovaniensia Analecta 101. Leuven.

Cruz-Uribe, E. (1988). Hibis Temple Project I. Translations, Commentary, Discussions and Sign List. San Antonio.

Cruz-Uribe, E. (1996). Comments on the Goddess Tayt. Varia Aegyptiaca 11(1), pp. 17-55.

CT = Faulkner, R. O. (2004). The Ancient Egyptian Coffin Texts. Oxford.

Dendera I = Chassinat, É. (1934). Le temple de Dendara. T. 1. Le Caire.

Dendera III = Chassinat, É. (1935). Le temple de Dendara. T. 3. Le Caire.

Dendera IV = Chassinat, É. (1935). Le temple de Dendara. T. 4. Le Caire.

Dendera VII = Chassinat, É. and Daumas, F. (1972). Le temple de Dendara. T. 7. Le Caire.

Dendera VIII = Chassinat, É. (1978). Le temple de Dendara. T. 8. Le Caire.

Dendera X = Cauville, S. (1997). Le temple de Dendara X. Les chapelles osiriennes (2 vols). Textes et planches, Le Caire.

Dendera Mammisi = Daumas, F. (1959). Les Mammisis de Dendara . Le Caire.

Davies, N. de G. (1953). The Temple of Hibis in El Khargeh Oasis. Part III. The Decoration. New York.

Drioton, É. (1926). Rapport sur les fouilles de Médamoud. Pt. 2., Les inscriptions. Le Caire.

Edfu I = Cauville, S. and Devauchelle, D. (1984-1987). Le temple d'Edfou. T. 1., Fasc. 1.-4. 2. éd. Le Caire.

Edfu II = Cauville, S. and Devauchelle, D. (1990). Le temple d'Edfou. T. 2., Fasc. 1.-2. 2. éd. Le Caire.

Edfu III = Chassinat, É. (1928). Le temple d'Edfou. T. 3. Caire.

Fakhry, A. (1961). The Monuments of Sneferu at Dahshur. Vol. II. The Valley Temple, Part I. The Temple Reliefs. Cairo.

Gabra, S. et al. (1941). Rapport sur les Fouilles d'Hermopolis Ouest (Touna el-Gebel). Le Caire. 
Gardiner, A. H., ed. (1935). The Temple of King Sethos I at Abydos, Vol. II, The chapels of Amen-Re', Re-'Harakhti, Ptah and King Sethos. London - Chicago

Gauthier, H. and Maspero, G. (1914). Catalogue General des Antiquitiés Egyptiennes du Musée du Caire: Sarcophages des époques persane et ptolémaïque. Vol. I. Le Caire.

Hornung, E. (1963). Das Amduat: Die Schrift des verborgenen Raumes. Ägyptologische Abhandlungen 7. Wiesbaden.

Hornung, E., ed. (1987). Texte zum Amduat. Aegyptiaca Helvetica 13-15. Basel.

Hornung, E. (2005). The Ancient Egyptian Books of the Underworld. London.

Kom Ombo = de Morgan, J., Bouriant, U., Legrain, G., Jéquier, G. and Barsanti, A. (1895). Cataloque des monuments et inscriptions de l'Égypte antique. 1. série., Haute Égypte., T. 2., Kom Ombos., Pt. 1. Vienne.

Kurth, D. (1994). Treffpunkt der Götter. Inschriften aus dem Tempel des Horus von Edfu. Zürich - München.

Kurth, D. (2017). "Aussen" und "Innen" in der Wanddekoration der ägyptischen Tempel griechisch-römischer Zeit. In: S. Baumann and H. Kockelmann, ed., Der ägyptische Tempel als ritueller Raum. Theologie und Kult in ihrer architektonischen und ideellen Dimension. Studien zur spätägyptischen Religion 17. Wiesbaden, pp. 457-471.

LÄ VI = Helck, W. and Otto, E., eds. (1968). Lexikon der Ägyptologie. Band VI. Wiesbaden.

Legrain, G. (1900). Le temple et les chapelles d'Osiris à Karnak Le temple d'OsirisHiq-Djeto, partie éthiopienne. I. Façade. II. Chambre A. III. Chambre B. IV. Chambre C. Recueil de traveaux relatifs à la philologie et à l'archéologie égyptiennes et assyriennes 22, pp. 125-136.

LGG I = Leitz, C. (2002). Lexikon der ägyptischen Götter und Götterbezeichnungen. Band I: $A-y$. Orientalia Lovaniensia Analecta 110. Leuven.

LGG VII = Leitz, C. (2002). Lexikon der ägyptischen Götter und Götterbezeichnungen. Band VII: S-d. Orientalia Lovaniensia Analecta 116. Leuven.

Lichtheim, M. (1945). The Songs of the Harpers. Journal of Near Eastern Studies 4:3, 178-212.

Moret, A. (1902). Le rituel du culte divin journalier en Égypte: d'après les papyrus de Berlin et les textes du temple de Séti 1er, à Abydos. Paris.

Míčková, D. and Wollnerová, D. (2018) The Story of Sinuhe. The outcome of the project "Ancient Egyptian stories of Middle Kingdom - translation, analysis and making the grammatical structure of the texts accessible to general linguistics", supported by Grant 
Agency of Charles University in Prague (project number 528216). [online] Czech Institute of Egyptology. Available at: https://cegu.ff.cuni.cz/wp-content/uploads/sites/50/2019/03/ Sinuhe-glos.pdf [Accessed 29 Jun. 2021].

Osing, J. et al. (1982). Denkmaler der Oase Dachla: aus dem Nachlass von Ahmed Fakhry. Mainz am Rhein.

Piankoff, A. (1954). The Tomb of Ramesses VI. Egyptian Religious Texts and Representations. Vol. I. New York.

PT = Allen, J. P. (2015). The Ancient Egyptian Pyramid Texts. Atlanta.

Rickert, A. (2011). Gottheit und Gabe. Eine ökonomische Prozession im Soubassement des Opettempels von Karnak und ihre Parallele in Kôm Ombo. Studien zur spätägyptischen Religion 4. Wiesbaden.

Rickert, A. (2014). Die ökonomischen Prozessionen im Überblick. In: A. Rickert and B. Ventker, ed., Altägyptische Enzyklopädien Die Soubassements in den Tempeln der griechisch-römischen Zeit. Soubassementstudien I/1. Studien zur spätägyptischen Religion 7. Wiesbaden, pp. 337-360.

el-Saady, H. (1994). Reflections on the goddess Tayet. Journal of Egyptian Archaeology 80, pp. 213-217.

Westendorf, W. (1978). Uräus und Sonnenscheibe. Studien zur Altägyptischen Kultur 6, pp. 201-225.

Wilkinson, R. H. (2003). The Complete Gods and Goddesses of Ancient Egypt. London.

Wilson, P. (1997). A Ptolemaic Lexikon. A Lexicographical Study of the Texts in the Temple of Edfu. Orientalia Lovaniensia Analecta 78. Leuven.

de Wit, C. (1955). Le rôle et le sens du lion dans l'Égypte ancienne. Luxor.

de Wit, C. (1958). Les inscriptions du Temple d'Opet, a Karnak I. Bruxelles.

de Wit, C. (1968). Les inscriptions du Temple d'Opet, a Karnak III. Bruxelles.

Wreszinski, W. (1912). Der Londoner Medizinische Papyrus (Brit. Museum Nr. 10059) und der Papyrus Hearst in Transkription, Uebersetzung und Kommentar. Leipzig.

Zecchi, M. (2001). The god Hedjhotep. Chronique d'Égypte 76(151-152), pp. 5-19. 